\title{
ENGINEERING PROPERTIES OF CONCRETE WITH SAND PARTIALLY SUBSTITUTED WITH CRUMB RUBBER
}

\author{
ADEYEMI OLUWASEUN ADEBOJE ${ }^{1}$, WILLIAMS KEHINDE KUPOLATI ${ }^{1}$, \\ EMMANUEL ROTIMI SADIKU ${ }^{2} \&$ JULIUS MUSYOKA NDAMBUKI ${ }^{1}$ \\ ${ }^{1}$ Department of Civil Engineering, Faculty of Engineering and the Built Environment, \\ Tshwane University of Technology, South Africa \\ ${ }^{2}$ Department of Chemical, Metallurgical and Materials Engineering, \\ Faculty of Engineering and the Built Environment, Tshwane University of Technology, South Africa
}

\begin{abstract}
The study was carried out to evaluate the influence of substituting sand content in concrete mixes with small proportions of crumb rubber on the mechanical and microstructural properties of concrete. The influence of crumb rubber on the mechanical properties of the concrete mixes was evaluated at early and prolonged ages, in addition to the conventional standard age. The microstructural property of the crumb rubber modified concrete samples was evaluated by testing and characterizing concrete samples obtained from the central part of the concrete cubes which were cured for 28 days. The properties of concrete samples were obtained from slump, bulk density, compressive strength, split tensile strength, scanning electron microscopy and energy dispersive spectroscopy tests. The results showed improvement in the mechanical properties of the concrete samples with increase in the age of curing in water. It further revealed that substitution of certain proportion of sand with crumb rubber could result in concrete with slightly improved mechanical properties of the crumb rubber modified concrete whereas substitution of greater quantities of sand with crumb rubber can lead to reduction in the strength parameters of the concrete samples. The microstructural characteristics of the concrete specimens substantiated the trend in the mechanical properties of the concrete samples.

Keywords: compressive strength, concrete, crumb rubber, mechanical properties, microstructure.
\end{abstract}

\section{INTRODUCTION}

Adequate utilization of waste materials such as crumb rubber for concrete production and construction purposes is an interesting area in recent researches across Africa [1]. Sufficient research, evaluation, analysis and experimental works are required to encourage the use of waste crumb rubber for concrete production [2]-[4].

Concrete is the most widely used construction material across the globe with its annual consumption rate at about 12 billion tonnes. The production of concrete is a process that is energy consuming and had continuously enhanced global warming [2], [3]. About $30 \%$ of energy consumed is used up in the construction industry [3], hence, it is essential to make use of construction materials with lesser thermal conductivity which can enhance efficiency of operational energy in concrete production [3]. The physical and microstructural properties of aggregates are the most important characteristics for achieving thermal insulation in concrete; therefore the use of thermal conductive aggregate and air entrainments can aid thermal resistance of concrete [3].

As a result of increase in the world population, human activities have increased [5]. This has led to astronomical increase in the waste generated from human activities while the total number of vehicles used worldwide has also increased [6], [7]. The astronomic growth in the rate of usage of vehicle globally results in the generation of huge quantities of waste rubber tyres [8], [9]. These waste tyres require effective disposal as landfills, incinerators and other waste disposal methods have proved ineffective for their disposal because they are non-degradable [10], [11]. When waste tyres are disposed on landfills they house 
insects, rodents and reptiles which are venomous, destructive or deadly to human and on the environment [12], [13].

Crumb rubber is produced from waste tyre rubbers by removing the strings of metal from the waste tyre rubbers, tearing them and eventually grinding them into desired grain sizes [14]-[17]. Crumb rubber is recently being evaluated as a material for partially substituting sand in concrete. Research has shown that substitution of sand content of concrete with crumb rubber can lead to reduction in the compressive strength of the rubberized concrete [18]-[21].

The experimental proof of the application of crumb rubber for concrete production can be a requisite step to presenting the recommendations to constituted authorities for the implementation and necessary legislation in order to enhance the preservation and conservation of the natural environment. This research investigated the suitability and effects of crumb rubber as a partial substitute of sand on the mechanical and microstructural properties of concrete.

\section{MATERIALS AND METHODS}

This section provides the materials used for the production of crumb rubber modified concrete and methods used for the evaluation of the mechanical and microstructural properties of the concrete samples.

\subsection{Materials}

The materials used for the production of concrete in this study were cement, sand, granite, crumb rubber and water.

\subsubsection{Cement}

The cement used for the study was Sephaku 32 CEM IV/B (V) $32.5 \mathrm{~N}$ which conformed to [22] and possessed specific gravity of 2.48. The cement sample is presented in Fig. 1(a).

\subsubsection{Sand}

Washed river sand with $4.75 \mathrm{~mm}$ maximum size was used for this study and is presented in Fig. 1(b).

\subsubsection{Granite}

The granite sample used for the study had $19 \mathrm{~mm}$ maximum size. The granite sample is presented in Fig. 1(c). The sand and granite samples used for the study were donated by Raumix Aggregates, Centurion, South Africa.

\subsubsection{Crumb rubber}

The crumb rubber used is shown in Fig. 1(d). The crumb rubber was donated by TOSAS recycling plant, Gemiston, South Africa.

\subsubsection{Water}

Potable water used for concrete production was obtained from the tap of Civil Engineering Laboratory, Tshwane University of Technology, Pretoria, South Africa. The water sample is presented in Fig. 1(e). 

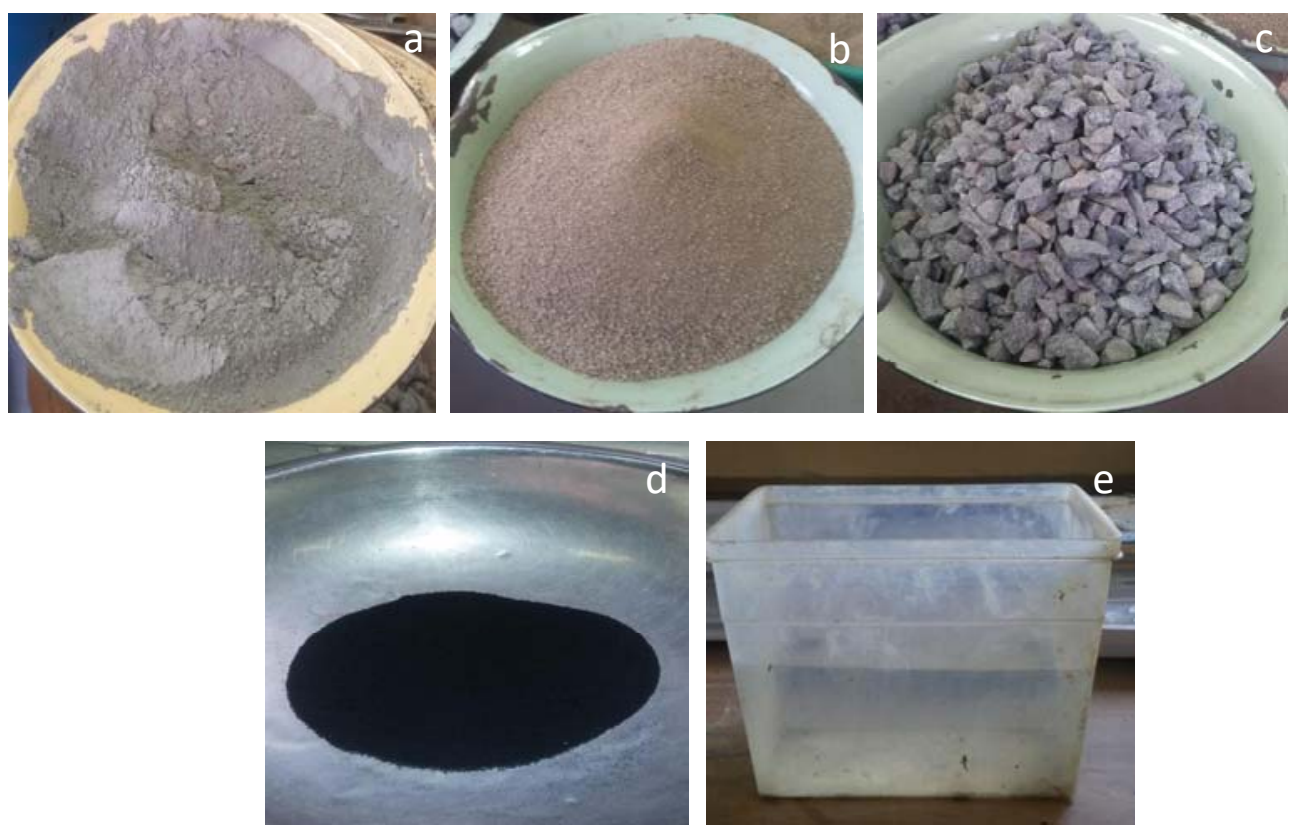

Figure 1: Pictures showing samples for concrete production. (a) Cement; (b) Sand; (c) Granite; (d) Crumb; and (e) Water.

\subsection{Methods}

The laboratory experiments conducted to determine the mechanical and microstructural properties of concrete were slump, bulk density, compressive strength, split tensile strength, scanning electron microscopy and energy dispersive spectroscopy.

\subsubsection{Slump}

Slump test was carried out to determine the workability of concrete samples produced for this work in line with [23]. It gives the reduction in the height of fresh concrete in the conical mould having height of $200 \mathrm{~mm}$, base of $300 \mathrm{~mm}$ and top diameter of $100 \mathrm{~mm}$.

\subsubsection{Bulk density}

Bulk density involves the determination of the weight of concrete cubes in hardened form at specified ages. The bulk density of concrete samples was carried out in line with [24].

\subsubsection{Compressive strength}

Compressive strength of concrete was conducted to determine the maximum compressive load required to cause failure to a $150 \times 150 \times 150 \mathrm{~mm}$ cubic concrete in line with [25].

\subsubsection{Split tensile strength}

Split tensile strength was conducted to determine the maximum indirect tensile load applied to cause failure to a $300 \mathrm{~mm}$ high concrete cylinder with $150 \mathrm{~mm}$ diameter in line with [26]. 


\subsubsection{Scanning electron microscopy}

The scanning electron microscope (SEM) was used to determine the microstructural formation of the different concrete samples. The concrete specimens used were cut from the centre of the different concrete cubes.

\subsubsection{Energy dispersive spectroscopy}

The energy dispersive spectroscope (EDS) was used to determine the elemental composition of the concrete samples. The specimen used for EDS was obtained in a similar way to that of SEM.

\subsection{Concrete mix design and preparation}

\subsubsection{Mix design}

The concrete samples used for this work were prepared with correct proportioning of $25 \mathrm{MPa}$ concrete in line with the specifications [27], [28]. Crumb rubber was used as partial substitute for 1, 2, 3 and 4\% sand in the different concrete mixes as presented in Table 1.

\subsection{2}

\subsubsection{Concrete preparation}

The concrete samples were prepared in the laboratory with the aid of electronic concrete mixer in line with [27]. Care was taken to prevent loss of any part of the concrete constituents while concrete mixing was done. The homogeneity of the concrete mixes was also maintained. The concrete cubes and cylinders were tested after they have been cured for 3, 7, 28, 90 and 120 days respectively.

\section{RESULTS AND DISCUSSION}

The outcomes of the experimental results for determining the microstructural and mechanical properties of crumb rubber modified concrete samples are presented as follows.

\subsection{Influence of partial replacement of sand with crumb rubber on the slump of concrete}

The slump value for the control sample of the concrete was $45 \mathrm{~mm}$. It reduced to 40,35 and $30 \mathrm{~mm}$ respectively when 1,2 and $3 \%$ sand were replaced with crumb rubber. The slump however remained $30 \mathrm{~mm}$ when $4 \%$ sand was substituted with crumb rubber. Crumb rubber has affinity for drawing water from concrete. Though the inclusion of crumb rubber led to reduction in the slump of concrete, the subsequent mixes were still workable when compared with the control sample. The range of the slump value obtained for the rubberized concrete complied with the specification for concrete with $19 \mathrm{~mm}$ maximum

Table 1: Mix proportioning for the substitution of sand with crumb rubber in concrete.

\begin{tabular}{lccccc}
\hline \multirow{2}{*}{ Materials } & \multicolumn{5}{c}{ Proportions of crumb rubber substituted } \\
\cline { 2 - 6 } & Control & $\begin{array}{c}1 \% \text { crumb } \\
\text { rubber }\end{array}$ & $\begin{array}{c}2 \% \text { crumb } \\
\text { rubber }\end{array}$ & $\begin{array}{c}3 \% \text { crumb } \\
\text { rubber }\end{array}$ & $\begin{array}{c}4 \% \text { crumb } \\
\text { rubber }\end{array}$ \\
\hline Cement $(\mathrm{gm})$ & 4,410 & 4,410 & 4,410 & 4,410 & 4,410 \\
Sand $(\mathrm{gm})$ & 7,973 & $7,893.3$ & $7,813.5$ & $7,733.8$ & $7,654.1$ \\
Granite $(\mathrm{gm})$ & 12,201 & 12,201 & 12,201 & 12,201 & 12,201 \\
Water $(\mathrm{ml})$ & 2,416 & 2,416 & 2,416 & 2,416 & 2,416 \\
Crumb rubber $(\mathrm{gm})$ & 0 & 79.7 & 159.5 & 239.2 & 318.9 \\
\hline
\end{tabular}


size of stone, moderately vibrated given as between 25 and $100 \mathrm{~mm}$ by [28]. This situation is similar to that in Batayneh et al. [18] where increase in crumb rubber content in the concrete mixes from the control to $20,40,60,80$ and $100 \%$ reduced the slump from 75 to $61,36,1810$ and 5\% respectively. However, the workability of the concrete mixes was not compromised.

3.2 Influence of partial replacement of sand with crumb rubber on the bulk density of concrete

The bulk density of the different concrete samples is presented in Table 2 . When the concrete samples were cured for 3 and 7 days respectively, the bulk density produced same result $\left(2,320 \mathrm{~kg} / \mathrm{m}^{3}\right)$ for the control sample and the sample with $1 \%$ sand substituted with crumb. The bulk density for $2 \%$ sand substituted with crumb rubber was $2310 \mathrm{~kg} / \mathrm{m}^{3}$ for both 3 and 7 days curing, while that of the samples with 3 and $4 \%$ sand substituted with crumb rubber was $2,300 \mathrm{~kg} / \mathrm{m}^{3}$. There was slight reduction in the bulk density with increase in the quantity of sand replaced with crumb rubber at both 3 and 7. For 28 days curing, the density was $2,330,2,320,2,310,2,300$ and $2,300 \mathrm{~kg} / \mathrm{m}^{3}$ for the control sample, 1, 2, 3 and $4 \%$ substitution of sand with crumb rubber respectively.

When the concrete samples were cured for 90 and 120 days, the bulk density of the control sample with $1 \%$ sand substituted with crumb rubber was 2,330 and $2,340 \mathrm{~kg} / \mathrm{m}^{3}$ respectively. The bulk density however maintained equal values of 2,330, 2,320, 2,310 and 2,310 for partial substitution of 1,2, 3 and 4\% sand with crumb rubber at both 90 and 120 days curing. Minimal reduction in the bulk density of the concrete samples occurred with increase in the crumb rubber content. Conclusively, the results of the bulk densities obtained for the control and substitution of 1, 2, 3 and $4 \%$ sand content with crumb rubber fall between 2,300 and $2,340 \mathrm{~kg} / \mathrm{m}^{3}$ which is within specification for normal weight concrete which ranged between 2,001 and 2,600 in line with [24].

\subsection{Influence of partial replacement of sand with crumb rubber on the compressive strength of concrete}

Table 3 shows the results of the compressive strength of the control and samples with 1,2, 3 and $4 \%$ sand substituted with crumb rubber. The results show that there was increment in the value of the compressive strength of concrete when $1 \%$ sand content was replaced with crumb rubber. However, substitution of 2,3 and $4 \%$ sand content with crumb rubber in the concrete mixes result in progressive reduction in the compressive strength at $3,7,28$,

Table 2: Bulk density of concrete with sand partially substituted with crumb rubber.

\begin{tabular}{lccccc}
\hline \multirow{2}{*}{$\begin{array}{l}\text { Quantities of sand } \\
\text { substituted with } \\
\text { crumb rubber (\%) }\end{array}$} & \multicolumn{5}{c}{ Bulk density of concrete $\left(\mathrm{kg} / \mathrm{m}^{3}\right)$} \\
\cline { 2 - 6 } & 3 & 7 & 28 & 90 & 120 \\
\hline 0 & 2,320 & 2,320 & 2,320 & 2,330 & 2,340 \\
1 & 2,320 & 2,320 & 2,330 & 2,330 & 2,330 \\
2 & 2,310 & 2,310 & 2,320 & 2,320 & 2,320 \\
3 & 2,300 & 2,300 & 2,310 & 2,310 & 2,310 \\
4 & 2,300 & 2,300 & 2,310 & 2,310 & 2,310 \\
\hline
\end{tabular}


Table 3: Compressive strength of concrete with sand partially substituted with crumb rubber.

\begin{tabular}{lccccc}
\hline \multirow{2}{*}{$\begin{array}{l}\text { Quantities of sand } \\
\text { substituted with } \\
\text { crumb rubber (\%) }\end{array}$} & \multicolumn{5}{c}{ Compressive strength of concrete (MPa) } \\
\cline { 2 - 6 } & 3 & 7 & 28 & 90 & 120 \\
\hline 0 & 16.0 & 18.5 & 27.0 & 36.5 & 37.5 \\
1 & 18.5 & 21.0 & 28.5 & 41.0 & 42.5 \\
2 & 16.0 & 19.0 & 25.0 & 37.0 & 39.0 \\
3 & 14.0 & 18.5 & 23.0 & 35.0 & 36.5 \\
4 & 12.0 & 18.0 & 21.5 & 32.0 & 34.5 \\
\hline
\end{tabular}

90 and 120 days of curing. The initial increment in the compressive strength value between the control and the sample with $1 \%$ sand substituted with crumb rubber is a major achievement of this research, it shows a good development for use of crumb rubber to achieve concrete with slightly improved compressive strength as against [19], [21], [29] where substitution of sand with crumb rubber only resulted in progressive decline or reduction in the value of the compressive strength of the rubberized concrete.

This work shows that there was substantial early strength recorded after 3 days curing, which may be due to the presence of fly ash in the cement, but there was little increment in the compressive strength of the concrete samples between 3 and 7 days curing. There were however substantial improvements in the compressive strength between 7 and 28 days and also between 28 and 90 days though the slightest improvement in the compressive strength occurred between 90 and 120 days which suggests that the concrete samples were either at or near the peak achievable strength at 120 days curing. The 28 days compressive strength shows $5.6 \%$ improvement with substitution of $1 \%$ sand with crumb rubber, $7.4 \%$ reduction with $2 \%$ substitution of sand with crumb rubber, $14.8 \%$ reduction with substitution of $3 \%$ sand with crumb rubber and $20.4 \%$ reduction with substitution of $4 \%$ sand with crumb rubber. Generally, the compressive strength improved for all the different mixes as the curing age increased in line with [30].

\subsection{Influence of partial replacement of sand with crumb rubber on the split} tensile strength of concrete

Table 4 shows the split tensile strength results for the control and samples which have 1, 2, 3 and $4 \%$ of their sand content replaced with crumb rubber. The split tensile strength increased with substitution of $1 \%$ sand with crumb rubber whereas it reduced consequently as 2,3 and $4 \%$ sand were substituted with crumb rubber for all the curing ages $(3,7,28,90$ and 120 days). There is a difference between the case reported in this work and those of [19], [21], [29], which showed no proof of improvement in the split tensile strength of the concrete samples with increase in the crumb rubber content as shown in this work.

Split tensile strength result of 28 days curing shows $5.7 \%$ improvement with substitution of $1 \%$ sand with crumb rubber. It however show $5.7 \%$ reduction with $2 \%$ substitution of sand with crumb rubber, $11.3 \%$ reduction with substitution of $3 \%$ sand with crumb rubber and $17 \%$ reduction with substitution of $4 \%$ sand with crumb rubber. 
Table 4: Split tensile strength of concrete with sand partially substituted with crumb rubber.

\begin{tabular}{lccccc}
\hline \multirow{2}{*}{$\begin{array}{l}\text { Quantities of sand } \\
\text { substituted with } \\
\text { crumb rubber (\%) }\end{array}$} & \multicolumn{5}{c}{ Split tensile strength of concrete (MPa) } \\
\cline { 2 - 6 } & 3 & 7 & 28 & 90 & 120 \\
\hline 0 & 1.60 & 1.90 & 2.65 & 3.70 & 3.75 \\
1 & 1.85 & 2.10 & 2.80 & 4.15 & 4.30 \\
2 & 1.55 & 1.90 & 2.50 & 3.65 & 3.90 \\
3 & 1.35 & 1.85 & 2.35 & 3.50 & 3.65 \\
4 & 1.20 & 1.85 & 2.20 & 3.20 & 3.45 \\
\hline
\end{tabular}

3.5 Influence of partial replacement of sand with crumb rubber on the microstructure of concrete

The SEM micrographs for the control and samples with 1, 2, 3 and 4\% sand contents substituted with crumb rubber are shown in Fig. 2(a)-(e) respectively. The more compact or denser the microstructure of the concrete sample is, the more improved the strength parameters and other mechanical properties. Fig. 2(a) appear dense but with little voids which was to be filled. Fig. 2(b) shows more compact and denser microstructure than Fig. 2(a) which indicates improved strength. On the other hand, the microstructures became looser, less dense and less compact from Fig. 2(b)-(d), and from Fig. 2(d) to (e). This shows weaker, less compact, looser microstructural formations from Fig. 2(c)-(e). The microstructure of the concrete samples has direct influence on the strength parameters shown and discussed in Sections 3.3 and 3.4.

The substitution of sand with crumb rubber beyond $1 \%$ can be responsible for the presence of crumb rubber around cement particles thereby weakening the bonding between the cement and water thereby slowing the hydration of cement paste and its efficacy of firmly binding the aggregates together. Large quantities of crumb rubber tend to create voids within the concrete matrix leading to pores which can reduce the strength of rubberized concrete in line with the suggestions of [19] and [29].

\subsection{Influence of partial replacement of sand with crumb rubber on the elemental composition of concrete}

The elemental composition of the control and samples with 1, 2, 3 and 4\% sand contents substituted with crumb rubber are presented in Table 5. Cement stands out as the material that aids hydration, binding of aggregates and strength enhancement in concrete [31]. According to Owens [31], the basic constituents of cement are calcium oxide $(\mathrm{CaO})$, silicon dioxide $\left(\mathrm{SiO}_{2}\right)$, aluminium oxide $\left(\mathrm{Al}_{2} \mathrm{O}_{3}\right)$ and ferric oxide $\left(\mathrm{Fe}_{2} \mathrm{O}_{3}\right)$.

Oxygen plays a major part in the microstructural formation [32] and strength enhancement of concrete [33] as the aforementioned compounds have abundant oxygen contents. In the same vein, the strength and microstructural denseness jointly embrace the importance of abundance of oxygen [32], [33]. Replacement of $1 \%$ sand with crumb rubber had the greatest oxygen content of $31.45 \%$ by weight together with having a high iron content of $48.62 \%$ by weight which enhanced the greatest strength and densest microstructure. The oxygen prevalence followed in the order of control, $2 \%, 3 \%$ and $4 \%$ 


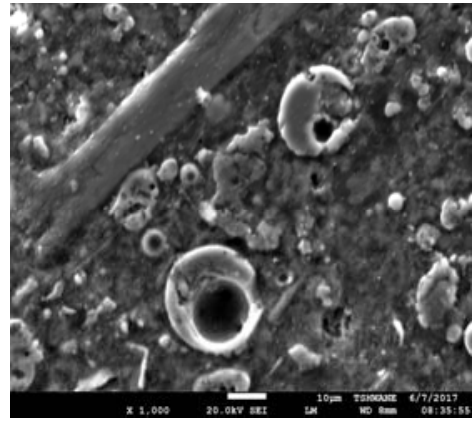

(a)

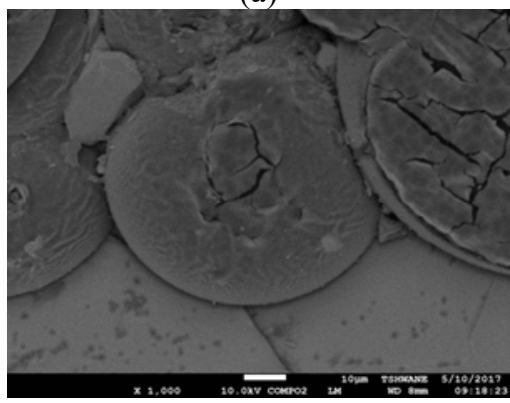

(c)

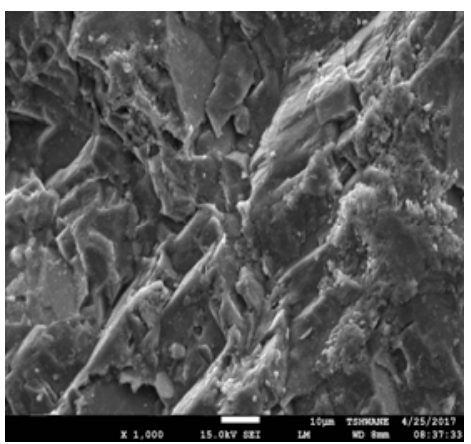

(b)

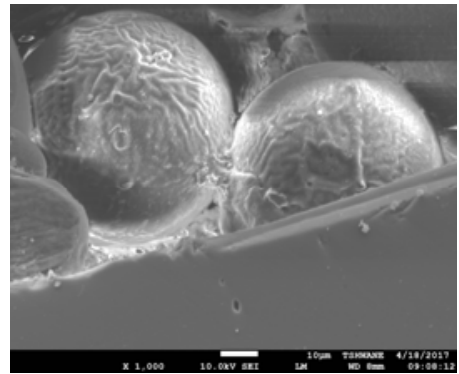

(d)

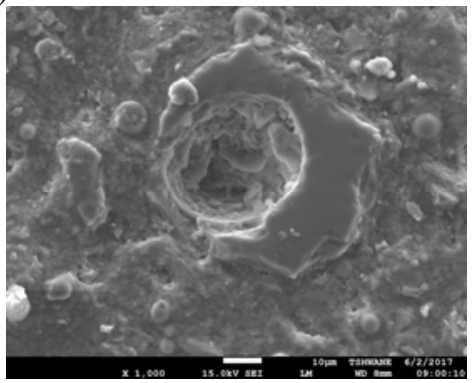

(e)

Figure 2: $\quad$ SEM micrographs for the substitution of sand with crumb rubber by (a) $0 \%$; (b) $1 \%$; (c) $2 \%$; (d) $3 \%$; and (e) $4 \%$ in concrete at 28 days.

sand replacements with crumb rubber which yielded 30.71, 29.49, 25.31 and $23.97 \%$ respectively. Furthermore, crumb rubber possessed great content of carbon which reduces the strength and loosen the microstructure as the its carbon content increased from 30.71 to 64.00 and 73.95 for the control, 2 and 3\% sand content replacement with crumb rubber respectively.

The chemical reactivity of materials having huge carbon contents such as crumb rubber is usually very low in the presence of heat or temperature [34]. This could inform the lack of compactness of carbon based crumb rubber which show weak or loose microstructural formation and results in strength reduction of concrete especially when more than $1 \%$ sand was substituted with crumb rubber [35], [36]. 
Table 5: Elemental composition of concrete with sand partially substituted with crumb rubber.

\begin{tabular}{|c|c|c|c|c|c|c|c|c|c|c|}
\hline \multirow[b]{2}{*}{ Elements } & \multicolumn{2}{|c|}{ Sample $F_{0}$} & \multicolumn{2}{|c|}{ Sample $F_{1}$} & \multicolumn{2}{|c|}{ Sample $F_{2}$} & \multicolumn{2}{|c|}{ Sample $F_{3}$} & \multicolumn{2}{|c|}{ Sample $F_{4}$} \\
\hline & $\begin{array}{c}\text { Weight } \\
\%\end{array}$ & $\begin{array}{c}\text { Atomic } \\
\%\end{array}$ & $\begin{array}{c}\text { Weight } \\
\%\end{array}$ & $\begin{array}{c}\text { Atomic } \\
\%\end{array}$ & $\begin{array}{c}\text { Weight } \\
\%\end{array}$ & $\begin{array}{c}\text { Atomic } \\
\%\end{array}$ & $\begin{array}{c}\text { Weight } \\
\%\end{array}$ & $\begin{array}{c}\text { Atomic } \\
\%\end{array}$ & $\begin{array}{c}\text { Weight } \\
\%\end{array}$ & $\begin{array}{c}\text { Atomic } \\
\%\end{array}$ \\
\hline $\mathrm{C}$ & 39.97 & 54.70 & - & - & 64.00 & 72.22 & 73.95 & 79.29 & 4.00 & 8.77 \\
\hline $\mathrm{O}$ & 30.71 & 31.55 & 31.45 & 57.84 & 29.49 & 24.99 & 25.31 & 20.37 & 23.97 & 39.40 \\
\hline $\mathrm{Mg}$ & 0.35 & 0.24 & - & - & - & - & - & - & - & - \\
\hline $\mathrm{Al}$ & 1.20 & 0.73 & - & - & 0.54 & 0.27 & - & - & 3.74 & 3.65 \\
\hline $\mathrm{Si}$ & 6.11 & 3.57 & - & - & 0.96 & 0.46 & 0.75 & 0.34 & 11.83 & 11.07 \\
\hline $\mathrm{P}$ & 2.28 & 1.21 & - & - & 3.65 & 1.60 & - & - & - & - \\
\hline $\mathrm{Ca}$ & 17.71 & 7.26 & - & - & 1.36 & 0.46 & - & - & 52.79 & 34.64 \\
\hline $\mathrm{Fe}$ & - & - & 48.62 & 25.62 & - & - & - & - & - & - \\
\hline K & 0.70 & 0.29 & - & - & - & - & - & - & 3.67 & 2.47 \\
\hline $\mathrm{Cl}$ & 0.97 & 0.45 & 19.93 & 16.54 & - & - & - & - & - & - \\
\hline
\end{tabular}

\section{CONCLUSIONS}

The investigation of the engineering properties of concrete with sand partially substituted with concrete can be concluded as follow:

i. The slump reduced from $45 \mathrm{~mm}$ for the control to $25 \mathrm{~mm}$ with the substitution of $4 \%$ sand with crumb rubber but the workability of the concrete was not affected.

ii. The bulk density of the crumb rubber modified concrete ranged between 2,300 and $2,340 \mathrm{~kg} / \mathrm{m}^{3}$, hence normal weight concrete result.

iii. The optimum utilization for the production of improved concrete is the substitution of $1 \%$ sand with crumb rubber.

iv. The microstructure of crumb rubber modified concrete was at the most compact or densest at $1 \%$ substitution of sand with crumb rubber.

v. Crumb rubber can be used for the production of mechanically and microstructurally improved concrete with the substitution of $1 \%$ sand content in concrete with crumb rubber.

\section{ACKNOWLEDGEMENTS}

The Department of Civil Engineering and the Faculty of Engineering and the Built Environment, Tshwane University of Technology, Pretoria South Africa are acknowledged for sponsoring the lead author for the publication and attendance of Waste Management Conference 2018.

\section{REFERENCES}

[1] Mohee, R. \& Simelane, T., (eds), Future Directions of Municipal Solid Waste Management in Africa, Africa Institute of South Africa, 2015.

[2] Kumaran, G.S., Mushule, N. \& Lakshmipathy, M., A review on construction technologies that enables environmental protection: rubberized concrete. American Journal of Engineering and Applied Sciences, 1(1), pp. 40-44, 2008.

[3] Najim, K.B. \& Hall, M.R., Thermo-physical and mechanical analysis of selfcompacting rubberised concrete (SCRC) mix classes. Proceedings of the 13th 
International Conference on Non-conventional Materials and Technologies (13 NOCMAT 2011), 22-24 Sep., Changsha, Hunan, China, 2011.

[4] Richardson, A., Coventry, K., Dave, U. \& Pienaar, J., Freeze/thaw performance of concrete using granulated rubber crumb. Journal of Green Building, 6(1), pp. 83-92, 2011. DOI: $10.3992 /$ jgb.6.1.83.

[5] Meadows, D. \& Randers, J., The Limits to Growth: The 30-Year Update, Routledge, 2012.

[6] Grimm, N.B. et al., Global change and the ecology of cities. Science, 319(5864), pp. 756-760, 2008.

[7] Godfray, H.C.J. et al., Food security: the challenge of feeding 9 billion people. Science, 327(5967), pp. 812-818, 2010. DOI: 10.1126/science.1185383.

[8] Paul, R., End-of-life management of waste automotive materials and efforts to improve sustainability in North America. WIT Transactions on Ecology and the Environment, vol. 120, WIT Press: Southampton and Boston, pp. 853-861, 2009.

[9] Saleh, T.A. \& Gupta, V.K., Processing methods, characteristics and adsorption behavior of tire derived carbons: A review. Advances in Colloid and Interface Science, 211, pp. 93-101, 2014.

[10] Plesuma, R., Megne, A., Mateusa-Krukle, I. \& Malers, L., Mechanical properties of the composite material based on modified scrap tires and polymer binder. Progress in Rubber, Plastics and Recycling Technology, 29(3), pp. 177-187, 2013.

[11] Zhou, Y., Fan, M., Chen, L. \& Zhuang, J., Lignocellulosic fibre mediated rubber composites: An overview. Composites Part B: Engineering, 76, pp. 180-191, 2015. DOI: /10.1016/j.compositesb.2015.02.028.

[12] Butu, A.W. \& Mshelia, S.S., Municipal solid waste disposal and environmental issues in Kano metropolis, Nigeria. British Journal of Environmental Sciences, 2(1), pp. 1-16, 2014.

[13] Muzenda, E., A Discussion on Waste Generation and Management Trends in South Africa, 2014.

[14] Aderinlewo, O.O., Risk Analysis of a Scrap Tire Embankment Using Influence Diagrams, University of Delaware, 2007.

[15] Eckstein, B., From your car to your patio: Using recycled tire products in building projects. Journal of Green Building, 7(3), pp. 16-31, 2012.

[16] Liang, T., Continuous devulcanization of ground tire rubber of different particle sizes using an ultrasonic twin-screw extruder. Doctoral dissertation, University of Akron, 2013.

[17] Hazeri, S., Energy harvesting in pneumatic tires through piezoelectric material and its life cycle environmental impact. Doctoral dissertation, Concordia University, 2017.

[18] Batayneh, M.K., Marie, I. \& Asi, I., Promoting the use of crumb rubber concrete in developing countries. Waste Management, 28(11), pp. 2171-2176, 2008. DOI: 10.1016/j.wasman.2007.09.035.

[19] El-Gammal, A., Abdel-Gawad, A.K., El-Sherbini, Y. \& Shalaby, A., Compressive strength of concrete utilizing waste tire rubber. Journal of Emerging Trends in Engineering and Applied Sciences, 1(1), pp. 96-99, 2010.

[20] Youssf, O., Mills, J.E. \& Hassanli, R., Assessment of the mechanical performance of crumb rubber concrete. Construction and Building Materials, 125, pp. 175-183, 2016. DOI: 10.1016/j.conbuildmat.2016.08.040. 
[21] Aravind, V.M., George, J., Jubeena, T.A., Basheer, S.M. \& James, S., Experimental investigation on Improvement of Rubcrete. International Journal of Innovative Research in Science, Engineering and Technology, 6(4), pp. 5572-5576, 2017.

[22] SANS 50197-1, South African National Standard. Composition, Specifications and Conformity Criteria for Common Cements, Pretoria, 2013.

[23] SANS 5862-1, South African National Standard. Concrete Tests - Consistence of Freshly Mixed Concrete-Slump Test, Pretoria, 2006.

[24] EN 12390-7, Testing Hardened Concrete: Density of Hardened Concrete, European Standard, 2009.

[25] SANS 5863, South African National Standard. Concrete Tests-Compressive Strength of Hardened Concrete. Pretoria, 2006.

[26] SANS 6253, South African National Standard. Concrete Tests-Tensile Splitting Strength of Concrete. Pretoria, 2006.

[27] SANS 5861-1, South African National Standard. Concrete Tests-Mixing Fresh Concrete in the Laboratory. Pretoria, 2006.

[28] Owens, G. (ed.), Fulton's Concrete Technology, Cement \& Concrete Institute, 2009.

[29] Akinyele, J.O., Salim, R.W. \& Kupolati, W.K., Production of lightweight concrete from waste tire rubber crumb. Engineering Structures and Technologies, 8(3), pp. 108-116, 2016. DOI: 10.3846/2029882x.2016.1209727.

[30] Sivakumar, T., Prabha, P., Bhuvaneshwari, B. \& Regupati, R., Characteristics of functionally modified foamed concrete by Nano-silica. IJERT, 3(5), 2014.

[31] Owens, G. (ed.), Fundamentals of Concrete, Cement and Concrete Institute, 2013.

[32] Zhang, L., Niu, J., Dai, L. \& Xia, Z., Effect of microstructure of nitrogen-doped graphene on oxygen reduction activity in fuel cells. Langmuir, 28(19), pp. 75427550, 2012.

[33] Jonkers, H.M., Thijssen, A., Muyzer, G., Copuroglu, O. \& Schlangen, E., Application of bacteria as self-healing agent for the development of sustainable concrete. Ecological Engineering, 36(2), pp. 230-235, 2010.

[34] Khale, D. \& Chaudhary, R., Mechanism of geopolymerization and factors influencing its development: a review. Journal of Materials Science, 42(3), pp. 729746, 2007.

[35] Sanchez, F. \& Sobolev, K., Nanotechnology in concrete-a review. Construction and Building Materials, 24(11), pp. 2060-2071, 2010.

[36] Shi, C. \& Zheng, K., A review on the use of waste glasses in the production of cement and concrete. Resources, Conservation and Recycling, 52(2), pp. 234-247, 2007. DOI: 10.1016/j.resconrec.2007.01.013. 